\title{
SEMIOTIC EVALUATION OF THE SYSTEMS OF SIGNS IN THE LITHUANIAN SCHOLASTIC GEOGRAPHICAL ATLASES
}

\author{
Inga Žalalienè \\ Department of Geography and Land Management, Faculty of Natural Sciences, Vilnius University, \\ M. K. Čiurlionio g. 21, 03101 Vilnius, Lithuania \\ E-mail: inga_zalaliene@yahoo.com
}

Received 06 June 2013; accepted 09 December 2013

\begin{abstract}
The article introduces the results of semiotic evaluation of maps in the Lithuanian scholastic geographical atlases. Cartographic signs were analysed using 1263 maps published in 17 Lithuanian scholastic geographical atlases. The chosen atlases were published by "Briedis", "Šviesa", "Alma littera", "Didakta” and "Pradai" publishing houses. The research method was developed based on the M. Dumbliauskienës methodology for evaluation of communicative quality of thematic maps (Dumbliauskiene 2000) which emphasises the semiotic aspect of evaluation. The mentioned methodology was partly transformed (the number of indices is reduced) taking into consideration the specific character of the end users of maps (young people striving for knowledge) and perception psychology.

The obtained results revealed the merits and faults of geographic production used by the Lithuanian schools which will be taken into account in further research (survey of perception of cartographic signs at school using questionnaires) and in preparing recommendations for improvement of the systems of cartographic signs in the maps of scholastic geographical atlases.
\end{abstract}

Keywords: cartographical semiotics, cartographic sign systems, thematic cartography, scholastic geographical atlases.

Reference to this paper should be made as follows: Žalalienè, I. 2013. Semiotic evaluation of the systems of signs in the Lithuanian scholastic geographical atlases, Geodesy and Cartography 39(4): 178-187.

\section{Introduction}

Maps as a means of conveying information have been used for a few thousand years. Though the first maps hardly resembled the modern cartographic production their purpose was the same - to convey different kinds of knowledge. Thus we can state that maps have especially old communicative traditions; they are even older than script. Maps are especially important in modern life. Symbols of cartographic material encode huge amounts of different information which are indispensible for modern people. Different cartographic production is designed for fulfilment of different tasks and is used by people of different age and education. Thus decoding, perception and assimilation of cartographic images require knowledge of cartographic language which should be in due course taught at school. The knowledge of cartographic language depends on the quality of cartographic production used by schools. It is of crucial importance that the information is conveyed in easily perceptible and memorisable language of cartographic signs.

It should be noted that the Lithuanian scholastic geographical cartographic production is a sore point which actually is neglected. In this country, there are very few scientific research works devoted to analysis of the quality of released cartographic production: Dumbliauskiene 2000, (the work contains the evaluation of school cartography production according to publishing groups, thematic sub-groups and character of usage and includes a summary account of results of qualimetric analysis), Ročiūtè (2009), Dumbliauskienè, Ročiūtè (2009), Ročiūtè, Dumbliauskienè (2009, 2011) (these articles report the results of semiotic evaluation of the systems of cartographic symbols used in higher forms (8-12) of Lithuanian secondary school 
and analysis (survey using questionnaires) of their perception), Bevainis (2009, 2011a, 2011b) (these articles contains the analysis and evaluation of cartographical images of educational maps and report the problems of graphic information loads). Therefore, the main objective of the present study is to find out the specific features of the systems of cartographic signs developed for Lithuanian scholastic geographical atlases. Systems of cartographic signs used by the Lithuanian publishing houses in scholastic geographical atlases (designed for higher forms) were chosen as the study object.

\section{Methods}

In order to make cartographic images readable, easily perceptible and easily assimilated, the compilation of maps should be based on certain rules and principles. The requirements for school maps depend on the age of target users. It is important that cartographic symbols are simple and easily memorisable. The maps designed for junior forms should use cartographic signs in their form and colour resembling the objects they represent (signs images and typical colours). In some cases it is desirable that cartographic signs are of identical colour and shape (stylized symbols of identical colour imitating the represented object). Without reference to the age of students, cartographic signs in map legends should be correctly semantically differentiated. It is especially recommended to name the groups of cartographic signs in maps targeted at younger students (e.g. mineral resources, settlements, power plants, etc.). The taxonomic differentiation and transitive expression also should be correct. The wellchosen cartographic background also is important as it helps to orientate in the map. In order to attract pupils' attention, the cartographic material (especially the one designed for younger pupils) should be graphically original. Taking into consideration the age of users, the graphic and information loads must be reasonable. Both overload (encumbering the readability of cartographic production, decoding of the information, perception and memorising) and underload (in this case mps are less informative) should be avoided.

The used method is not new. I was applied in 2009 only for investigation of perception of cartographic signs in economic maps from the Lithuanian scholastic geographical atlases (Ročiūtè 2009; Dumbliauskiené, Ročiūtė 2009; Ročiūtė, Dumbliauskienè 2009). For this reason, the main principles of the present research are briefly overviewed emphasising only the attributes of the evaluated indices (Tables 1 and 2).
As was mentioned, the method for semiotic evaluation of cartographic signs was developed by partly transforming the already existing method for evaluation of communicative quality of thematic maps (Dumbliauskiene 2000) and taking into consideration the psychological principles of perception (Kaffemanas 1997, 2001, 2002; Vaitkevičius 2002; MacEachren 2004; Stanikūnas et al. 2004; Gurčinienė, Šoliūnas 2005; Wiegand 2006; Gurčinienè 2007; Martišius 2008).

The systems of cartographic signs used in the Lithuanian scholastic geographical atlases were analysed in three semiotic aspects. For each of them the evaluation indices were distinguished which are most important for correctness of signs and for their comprehension, assimilation and memorising.

1. The semantic analysis focuses on the relations between signifiers (signs) and denotations (objects they stand for). The associative capacity of the shape and colour of signs were evaluated. It is important that the signs used in maps preserve the typical attributes of denoted objects, phenomena and processes in terms of shape and colour (Dumbliauskienè 2002; Bertin 1981). The associative capacity of shape was analysed based on the following features: imitating or stylised characters (they also are called icons; they are small pictures (drawings or photographs), e.g. $\boldsymbol{Q}$ - cotton, $\boldsymbol{M}_{\text {- cattle), symbolic characters }}$ (they denominate the objects, phenomena or processes according to their typical attribute, e.g. $\Delta$ - chemical industry, - theatre), and abstract conventional signs (signs which signify objects, phenomena or processes by agreement within a certain system of symbols, e.g. $\diamond$ - nickel ore, $\triangle$ - ironstone). Analysing the associative capacity of colour, identical (e.g. $\mathrm{O}$ - citruses, of grapes), symbolic (e.g. - automotive industry) and indifferent (e.g. - grapes) colours were distinguished.

2. The syntactic analysis is focused on the interrelations between signs. This aspect helps to seek correctness of signs taking into consideration their intrinsic links (which reflect the bonds between the real denoted objects). The information conveyed by maps compiled with respect to this aspect is more easily perceived by readers. The study also includes the evaluation of semantic (related with cartographic signs and their grouping according to certain attributes) and taxonomic differentiations (showing hierarchical bonds of cartographic signs existing in reality) and transitive expression (it shows the correctness of quantitative, qualitative and proportional scales used in a map; transitive expression manifests through 
variations of the size, colour and colour intensity of cartographic signs as well as intensity of shading) (Table 1).

The relation (communication and perception) of the users with the system of cartographic signs is analysed in pragmatic aspect. Attention is focused on the whole of cartographic signs, general cartographic image and its comprehension. The following evaluation indices are distinguished: graphic (characterized by the density of cartographic signs and letterings) and informative (it depends not only on the graphic load but also on characteristics of cartographic signs, gradations, links between signs and textual information, links of the elements of thematic contents with the cartographic basis, etc.) loads (Berliant 1986, 2003). It must be born in mind that the perception ability of individual readers differs depending on the age, education, knowledge of the field and even gender. The mentioned loads are evaluated visually, optimality of cartographic basis (it facilitates spatial orientation, perception and assimilation of the conveyed information; it should be pointed out that all types of maps should depict hydrographic and settlement networks; also they should represent cartographic grid and administrative distribution. The nature maps often depict relief and forests; the maps of social themes depict motor road and railway networks. The composition and number of the elements of cartographic basis are predetermined by the theme of the map, its scale and destination), graphic originality (unusual map elements, expressive forms, bright well matched colours, nonstandard design, original supplementary material (photographs, caricatures, etc.). All these features attract users' attention, raise interest,

Table 1. Features of semantic and taxonomic differentiation and transitive expression and their characteristics

\begin{tabular}{|c|c|}
\hline \multirow{6}{*}{ 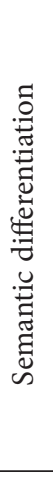 } & Correct \\
\hline & $\begin{array}{l}\text { In the legend, the cartographic signs are clearly grouped according to certain features. The distinguished groups are } \\
\text { titled. } \\
2-3 \text { semantic groups of signs are used. }\end{array}$ \\
\hline & Partly correct \\
\hline & $\begin{array}{l}\text { Most of the cartographic signs in the legend are grouped according to certain features but the semantic groups not } \\
\text { always are titled. } \\
\text { Semantic groups are distinguished yet untitled. Moreover, different groups of signs are not separated (for example by } \\
\text { adding space between lines). This makes the semantic differentiation difficult to comprehend. }\end{array}$ \\
\hline & Not expressed \\
\hline & $\begin{array}{l}\text { The map depicts one object, phenomenon or process with few features. Therefore, the legend is simple. Only a few signs } \\
\text { are explained. }\end{array}$ \\
\hline \multirow{6}{*}{ 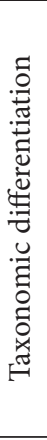 } & Correct \\
\hline & $\begin{array}{l}\text { The relation with a real object, phenomenon or process is clearly visualised through respective features: shape and size of } \\
\text { signs and colour and shading intensity. } \\
\text { A simple hierarchic structure of signs is use: } 3-4 \text { hierarchic ranks of signs are dominant. }\end{array}$ \\
\hline & Partly correct \\
\hline & $\begin{array}{l}\text { Most of the used cartographic signs are correctly taxonomically differentiated yet not all of them. } \\
\text { The hierarchy of cartographic signs is poorly visualised, e.g. graphic signs hardly differ in size and the differences of line } \\
\text { thickness or colour and shading intensity are hardly discernible. }\end{array}$ \\
\hline & Not expressed \\
\hline & $\begin{array}{l}\text { The theme of the map is narrow and does not require visualisation of the links between the cartographic signs and real } \\
\text { objects, phenomena or processes (few cartographic signs are used; the hierarchic links between signs are absent). }\end{array}$ \\
\hline \multirow{6}{*}{ 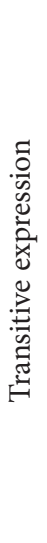 } & Correct \\
\hline & $\begin{array}{l}\text { The colour and shading scales and size of signs are not random. They are selected following principles of logic and } \\
\text { semantic rules. The scales clearly visually differ in size: colour transitiveness and intensity are correct, shading intensity is } \\
\text { clear as is the difference between the sizes of the used signs. } \\
\text { The number of intervals is optimal: maximum 5-6 intervals. }\end{array}$ \\
\hline & Partly correct \\
\hline & $\begin{array}{l}\text { The colour and shading scales and size of signs are not random. They are selected following principles of logic and } \\
\text { semantic rules. The small and large scales are not clearly discernible: distinguishing between colours and shades and size } \\
\text { of signs requires effort. } \\
\text { The scale interval is at variance with the principle of transition: a colour, a shade or one of the signs falls out of the } \\
\text { context. } \\
6-8 \text { or even more intervals are used. }\end{array}$ \\
\hline & Not expressed \\
\hline & the map does not require transitive expression index. \\
\hline
\end{tabular}


strengthen the impression, increase readability of the map and contribute to easy perception and memorising of the conveyed information), standardisation level (standardisation of cartographic signs implies regulation of the shapes and size of signs, colours and their intensity, orientation of signs, and texture. These regulations should be obeyed when compiling maps (Dumbliauskiene 2004); standardisation increases the readability of cartographic production, perception and assimilation of information), and readability (it depends on the above discussed indices) (Table 2).

\section{Results of semiotic analysis}

The number of the analysed cartographic signs is unequally distributed in atlases. The greatest numbers of signs (some of them repeat themselves) in are used in the "World atlas" published by "Alma Littera" scholastic atlas "The Earth" published by "Briedis" (Table 3).

Grouping of all cartographic signs into point, line (signs lines, signs vectors) and areal patterns (Fig. 1) showed that the Lithuanian scholastic geographical atlases are predominated by areal signs (area patterns) which account for almost $49 \%$ of the total of used

Table 2. Evaluation indices of graphic and informative loads, cartographic basis, graphic originality, standardisation level and readability and their characteristics

\begin{tabular}{|c|c|}
\hline \multirow{6}{*}{ 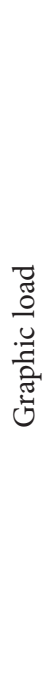 } & Overload \\
\hline & $\begin{array}{l}\text { Very many signs and letterings: } \\
\text { - cartographic signs and letterings drown in each other; } \\
\text { - signs are indiscernible and hardly recognizable; } \\
\text { - letterings are almost illegible; } \\
\text { - there are difficulties in associating letterings with objects. }\end{array}$ \\
\hline & Acceptable \\
\hline & $\begin{array}{l}\text { Letterings and signs are not many: } \\
\text { - signs and letterings do not drown in each other; } \\
\text { - signs are easily discernible and recognizable; } \\
\text { - letterings are easily readable; } \\
\text { - letterings are easily associated with objects. }\end{array}$ \\
\hline & Underload \\
\hline & $\begin{array}{l}\text { Mapping is performed by cartogram method; } \\
\text { Low density of signs and letterings; } \\
\text { Many "free" areas: signs and letterings are concentrated in one or a few small areas. }\end{array}$ \\
\hline \multirow{6}{*}{ 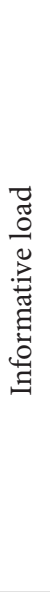 } & Overload \\
\hline & $\begin{array}{l}\text { A great variety of signs: signs of different shapes and colours are used; } \\
\text { A great variety of letterings: different font types and sizes; different font colours; } \\
\text { Especially detailed quantitative and qualitative scales are used (more than five intervals); } \\
\text { A complicated hierarchic sign structure is used. }\end{array}$ \\
\hline & Optimal \\
\hline & $\begin{array}{l}\text { Information is represented using } 2-3 \text { semantic groups of signs; } \\
\text { The hierarchic structure of signs is simple: } 3 \text { hierarchic levels are dominant; } \\
\text { The qualitative and quantitative scales have } 5 \text { intervals or categories at most. }\end{array}$ \\
\hline & Underload \\
\hline & $\begin{array}{l}\text { Only one object, phenomenon or process is depicted; } \\
\text { A few objects, phenomena or processes are depicted yet their territorial distribution is limited; they have few } \\
\text { informative attributes. }\end{array}$ \\
\hline \multirow[b]{2}{*}{ 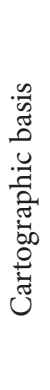 } & Optimal \\
\hline & $\begin{array}{l}\text { When most of the following elements are plotted: } \\
\text { Hydrographic network, i.e. rivers, lakes, seas and other big bodies of water with names indicated (irrespective of the } \\
\text { theme or scale of the map); } \\
\text { Capitals and main cities of countries with names given (irrespective of the theme and scale of the map); } \\
\text { Administrative territorial distribution (irrespective of the theme or scale of the map); } \\
\text { Cartographic grid (irrespective of the theme or scale of the map); } \\
\text { Relief (with respect to the theme of the map); } \\
\text { Forests (flora) (with respect to the theme of the map); } \\
\text { Network of motor roads and railways (with respect to the theme of the map). }\end{array}$ \\
\hline
\end{tabular}


Continued Table 2

\begin{tabular}{|c|c|}
\hline \multirow{4}{*}{ 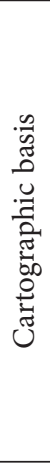 } & edium optimal \\
\hline & $\begin{array}{l}\text { When only some of the elements of cartographic basis listed in the section "Optimal" are plotted. Some of the elements } \\
\text { due to be plotted with respect to the scale and theme of the map are missing, e.g.: } \\
\text { - cartographic grid is missing; } \\
\text { - names of some administrative territories are not given (in small scale maps); } \\
\text { - not all capital cities of the countries are plotted and named (in small scale maps). } \\
\text { The elements of cartographic basis are rather generalised, i.e. lack detail, e.g.: the river network is too generalised, } \\
\text { names of rivers are not given (in the maps of all scales). }\end{array}$ \\
\hline & \begin{tabular}{|l|} 
Not optimal \\
\end{tabular} \\
\hline & $\begin{array}{l}\text { When are plotted: } \\
\text { - Only administrative territorial distribution without indication of the names of the plotted territories. } \\
\text { - Administrative territorial distribution and a few largest rivers without names (in large scale maps). }\end{array}$ \\
\hline \multirow{6}{*}{ 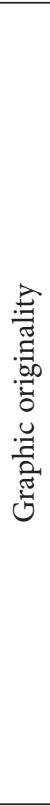 } & Pronounced \\
\hline & $\begin{array}{l}\text { Original depiction techniques attracting user's attention are used: } \\
\text { - technique of symbols - especially original imitating/stylised (photographs) or unusual symbols are used; } \\
\text { - technique of qualitative/ quantitative background - especially well matched (between themselves and with other } \\
\text { signs) colours and original shades are used to attract user's attention. } \\
\text { An original cartographic basis is used, e.g. shadowed relief strengthening perception. } \\
\text { Original shades are used. } \\
\text { Nonstandard original letterings are used. }\end{array}$ \\
\hline & Moderate \\
\hline & $\begin{array}{l}\text { Only a small part of the graphic image is marked by original expression: e.g. only a few attractive cartographic signs } \\
\text { (imitating/stylised) are used which hardly facilitate the general perception of the cartographic image; } \\
\text { Well matched colours and/or shades are used yet they are not strongly attracting attention; } \\
\text { Traditional easily readable letterings are used. }\end{array}$ \\
\hline & Absent \\
\hline & $\begin{array}{l}\text { Undistinguished depiction techniques are used, which do not attract user's attention and do not facilitate (in many cases } \\
\text { even encumber) the readability of the cartographic "text": } \\
\text { - the cartographic signs used are simple and undistinguished; in the majority of cases they are difficultly perceivable } \\
\text { abstract conventional signs; } \\
\text { - the colours used lack expressivity; they are not contrasting and not harmonised; } \\
\text { - the shades are undistinguished and not attractive; } \\
\text { - the letterings are simple and undistinguished. }\end{array}$ \\
\hline \multirow{6}{*}{ 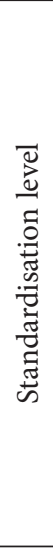 } & Standardised \\
\hline & $\begin{array}{l}\text { Nationally and internationally standardised mandatory systems of cartographic signs are used. Such are geological, soil } \\
\text { and synoptic maps. Usually maps of these types are easily readable and perceptible. Those who have practice in reading } \\
\text { these thematic maps usually do not need to refer to the legend. }\end{array}$ \\
\hline & Partly standardised \\
\hline & $\begin{array}{l}\text { Institutionally standardised systems of signs are used. In the course of time, standards of representing certain objects } \\
\text { become established (e.g. colours for different zones in maps of vegetation zones or colours representing different stands } \\
\text { in maps of forests) though not approved by appropriate organisations. Usually, cartographic signs of this kind are } \\
\text { standardised based on one attribute: colour or shape. These maps are sufficiently easily readable because at least some of } \\
\text { the used signs can be recognised without referring to the legend; especially if the user has practice of reading maps of } \\
\text { these kinds. }\end{array}$ \\
\hline & Not standardised \\
\hline & $\begin{array}{l}\text { The used systems of cartographic signs are not internationally, nationally or institutionally standardised. In order to } \\
\text { understand them, reference to the legend is necessary what encumbers fast reading and perception. }\end{array}$ \\
\hline \multirow[b]{2}{*}{ 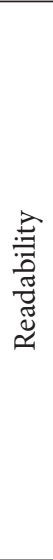 } & Good \\
\hline & $\begin{array}{l}\text { Imitating/stylised and/or symbolic (especially ostensive) signs are used of identical or symbolic colour; } \\
\text { The used signs and letterings do not drown in each other; } \\
\text { The colour (and its intensity) and size of signs make possible their easy discernment on the background; } \\
\text { Signs are easily distinguished from each other; } \\
\text { Letterings can be easily attributed to relevant objects; } \\
\text { Cartographic signs in legends are correctly semantically and taxonomically differentiated; } \\
\text { Optimal cartographic basis is used; } \\
\text { Correct colour and/or shading scales are used. They are not random but selected sticking to the principles of logic and } \\
\text { semantic rules; } \\
\text { Transitive expression index is represented by an optimal number of intervals: maximum 5-6 intervals; } \\
\text { The information is represented using } 2-3 \text { semantic groups of signs; } \\
\text { The qualitative and quantitative scales are composed of } 5 \text { intervals or categories at most; } \\
\text { The used cartographic signs are internationally and/or nationally standardised; } \\
\text { The cartographic methods employed are original and attracting user's attention. }\end{array}$ \\
\hline
\end{tabular}




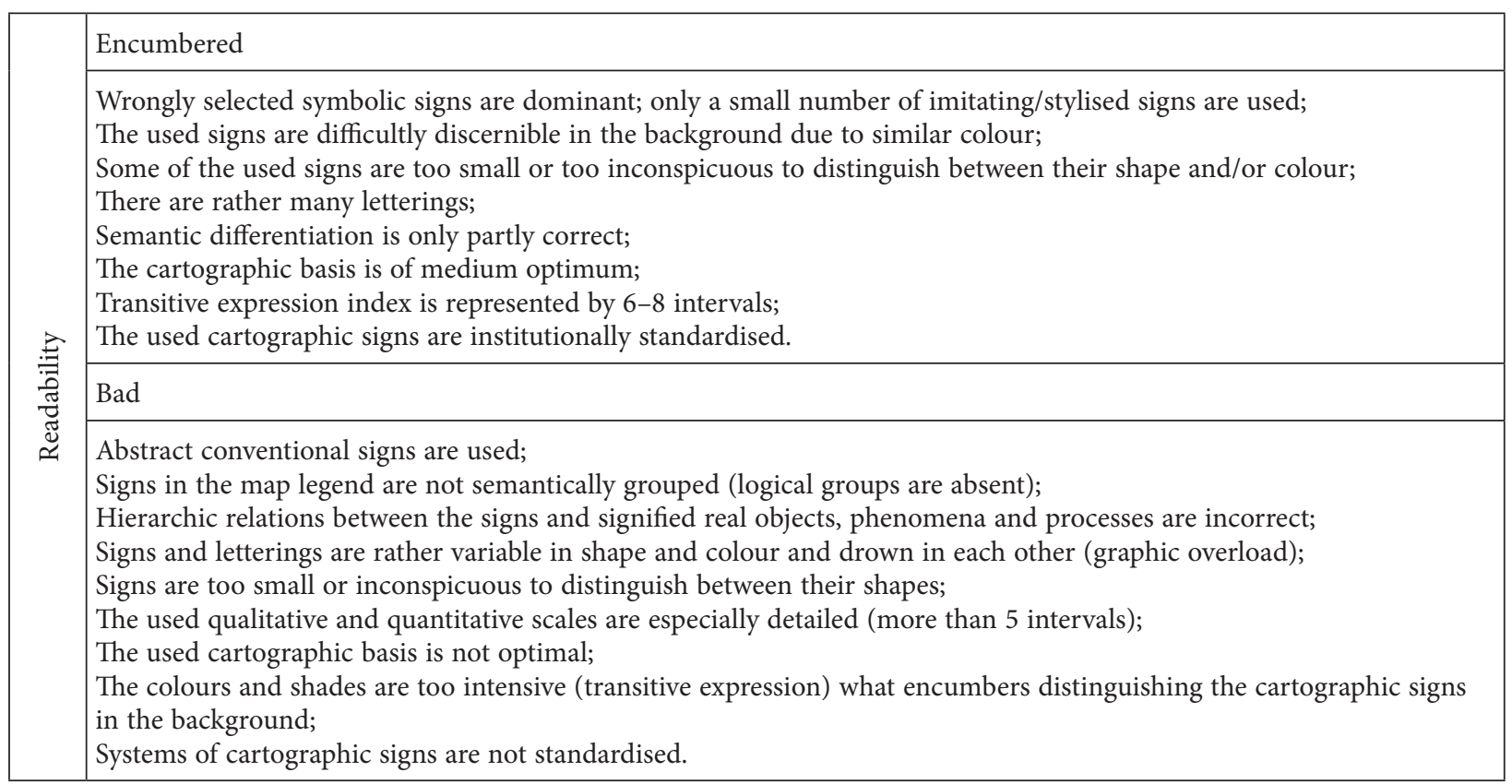

Table 3. Analysed scholastic geography atlases and the number of cartographic signs in them

\begin{tabular}{|c|c|c|}
\hline & Analysed scholastic geography atlases & $\begin{array}{l}\text { The number of } \\
\text { cartographic signs }\end{array}$ \\
\hline \multicolumn{3}{|c|}{ „Briedis“ publishing house: } \\
\hline I atlas & The Earth. Geographical Atlas for the 6th form (2004) & 89 \\
\hline II atlas & The Earth. Interactive teaching geographical Atlas for the 6th form (2010) & 151 \\
\hline III atlas & The Earth. Geographical Atlas for the 7th form (2004) & 494 \\
\hline IV atlas & The Earth. Interactive teaching geographical Atlas for the 7th form (2010) & 574 \\
\hline $\mathrm{V}$ atlas & The Earth. Geographical Atlas for the 8th form (2007) & 892 \\
\hline VI atlas & The Earth. Interactive teaching geographical Atlas for the 8th form (2011) & 786 \\
\hline VII atlas & Geographical Atlas of Lithuania for the 9th form (1999) & 404 \\
\hline VIII atlas & The Earth. Geographical Atlas for the 9th form (2005) & 371 \\
\hline IX atlas & The Earth. Geographical Atlas for the 10th form (2007) & 424 \\
\hline $\mathrm{X}$ atlas & The Earth. Scholastic Geographical Atlas (2006) & 1974 \\
\hline \multicolumn{3}{|c|}{ „Šviesa“ publishing house: } \\
\hline $\mathrm{XI}$ atlas & We are many - the World is one. Geographical Atlas for the 6th form (2008) & 252 \\
\hline XII atlas & Geographical Atlas for the 7-8th forms (2011) & 1033 \\
\hline XIII atlas & Lithuania Europe the World. Geographical Atlas for the 9th-10th forms (2007) & 750 \\
\hline XIV atlas & Atlas of Integrated Geography for Schools (2005) & 1198 \\
\hline \multicolumn{3}{|c|}{ „Alma littera“ publishing house: } \\
\hline $\mathrm{XV}$ atlas & World Atlas (2008) & 1983 \\
\hline \multicolumn{3}{|c|}{ „Pradai“ publishing house: } \\
\hline XVI atlas & Universal World Atlas (1996) & 1180 \\
\hline \multicolumn{3}{|c|}{ „Didakta“ publishing house: } \\
\hline XVII atlas & New World Atlas (2009) & 1380 \\
\hline
\end{tabular}


cartographic signs. This is predetermined by a rather large number of small-scale maps in which the information is conveyed using qualitative or quantitative background and isoline (using colours for the interlayers) methods. These methods are used e.g. in maps depicting the quality of life index, birth rate, number of sunny days per year, amount of precipitation, etc. Also there are rather many medium-scale maps predominated by territorial distribution of objects, phenomena and processes where area patterns are used: e.g. agricultural maps depicting the distribution areas of vegetables, fruits, domestic animals. The cartogram method also is rather popular for spatial representation of agro cultures (for example the area of wheat, in ha, per 100 ha of cultivated soil) or population per unit territory (e.g. $1 \mathrm{sq} \mathrm{km}$ ), etc.

Point signs are not less important in the analysed atlases (Fig. 1) where they account for about $39 \%$ of

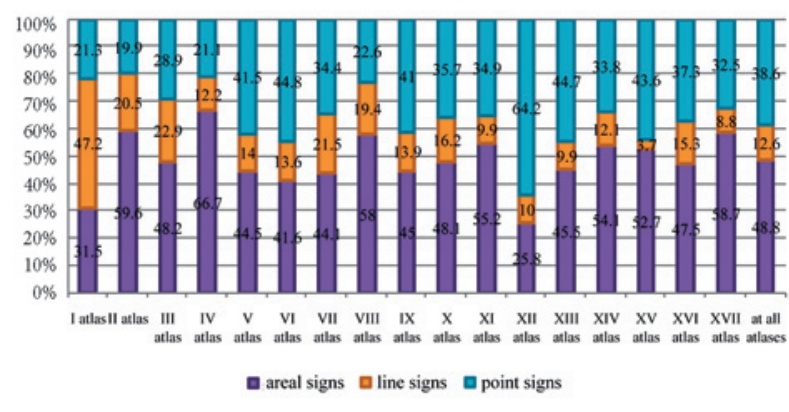

Fig. 1. Distribution of point, line and area patterns in the analysed scholastic geographical atlases (\%)

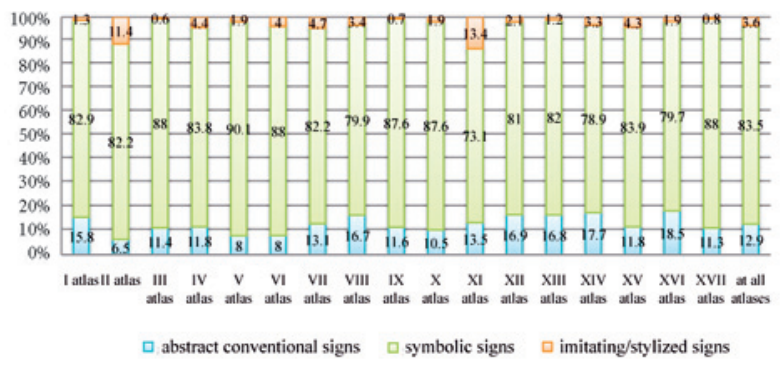

Fig. 2. Association capacity of the shape of signs in the analysed maps of scholastic geographic atlases (\%)

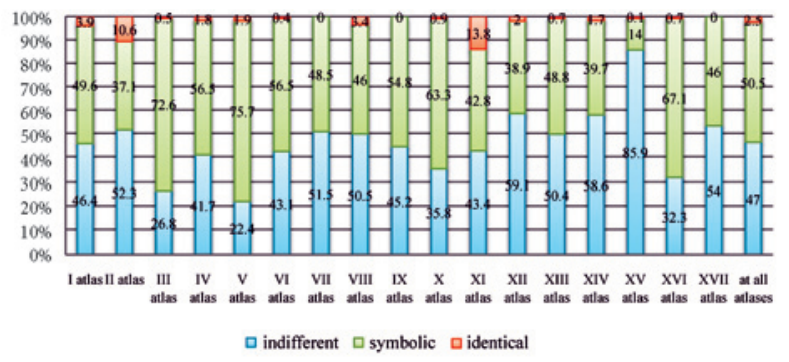

Fig. 3. Association capacity of the cartographic colours in the analysed maps of scholastic geographic atlases (\%) the total. This group of signs is especially often used in economic maps. This is so because the signified objects mainly are concentrated in points. The most widespread point objects are: mineral deposits, their treatment plants and other industrial centres, power plants, sea ports, air fields, etc.

The linear objects are least frequently signified in scholastic atlases. The line signs only account for $14 \%$ of the total (signs lines, signs vectors) (Fig. 1). These cartographic signs are used for representing the boundaries of different areas and spread directions of some phenomena and objects. For example, lines of different colour, thickness and texture are used to signify rivers, climate belts, boundaries of the tectonic plates, tectonic fault zones, navigation channels, railways, networks of motor roads, boundaries of oceans, etc. Signs vectors are used even more rarely. They are used for representation of expedition itineraries and directions of navigation (at the time of the great geographic discoveries), sea currents, tectonic plate movement, drifting of icebergs, and various natural disasters.

The semantic analysis of the Lithuanian scholastic geographical atlases showed that in most cases the resemblance of the shape of signifiers with the represented objects is conveyed using the symbolic signs, e.g.: 首 - crude oil, $\Delta$ - chemical industry, - castles, etc. (Fig. 2). Signs of this type account for more than $83 \%$ of the total of cartographic signs used in these maps. Abstract signs (e.g. $\bigcirc$ - metal processing, $\bigcirc$ - tee trees, - - earth quakes) account for $12.9 \%$. The rarest in the scholastic atlases are imitating/stylised cartographic signs which are easily understandable and memorisable, e.g.: 哭 - grapes, $\mathbf{Q}$ cotton, $\overrightarrow{2}$ - pigs, - cattle). They only account for $3,6 \%$ of the total of cartographic signs used in the studied atlases.

Association capacity of colours (resemblance of the cartographic colours to the colours of real objects, phenomena or processes), facilitating recognition of represented objects, is another index of key importance in cartography. Yet it is rather difficult to choose colours identical to the represented object, phenomenon or process.

It was determined that cartographic signs of symbolic colours (e.g. $\leadsto$, (2), 园, ↔田) (Fig. 3) were most frequently used in the studied atlases. They account for slightly more than a half of the total. Cartographic signs of indifferent colour (e.g. red rather frequently and accounted for $47 \%$ of the total. The cartographic signs with identical colours (e.g. 
A7, $Q, 0$ ) are fewest in the mps of geographical atlases. They account for $2.5 \%$.

Syntactic analysis of Lithuanian scholastic geographical atlases showed that in the legends of maps the cartographic signs usually are correctly semantically differentiated (Fig. 4). In more than a half of the analysed maps (54.1\%), cartographic signs are correctly semantically grouped though in many cases these groups are not titled. In simple maps - one or a few isolated objects, phenomena or processes are depicted - the semantic differentiation is not expressed (and it is not necessary). Such maps account for more than one third of the analysed maps. Only in the legends of $7.3 \%$ of analysed maps cartographic signs are partly correctly semantically grouped.

Taxonomic (hierarchic) signs (Fig. 5) representing the real relationships between objects, phenomena and processes are very rare in the analysed scholastic maps. In almost $83 \%$ of analysed maps, taxonomic differentiation is not expressed. The correct taxonomic differentiation was determined only in $16.6 \%$ of analysed maps. Only in $0.5 \%$ of maps the hierarchic relations are represented partly correctly.

It was observed (Fig. 6) that in more than a half of analysed maps (59\%) the transitive expression is correct. In almost $1 / 4$ of maps the transitive expression is partly correct and in slightly more than $16 \%$ of maps it is absent.

Pragmatic analysis showed that the graphic load of atlases published by different publishing-houses varies; the distribution of cartographic signs is uneven (Fig. 7). In some maps signs are concentrated in certain areas whereas other areas are almost empty. The general load of such maps can be evaluated (visually) as acceptable when it does not encumber readability. The load is not acceptable when maps abound in concentrations of signs and the number of signs within them is very high what makes it difficult to link them with the letterings.

Analysis revealed that the load (by visual evaluation) of more than a half of all analysed scholastic geographical atlases is acceptable (Fig. 7). Yet even about $40 \%$ of analysed maps are graphically underloaded. Maps overloaded with graphic elements are especially rare ( $1.5 \%$ of the total).

The research also showed that the Lithuanian scholastic geographical atlases are not overloaded with information (Fig. 8). In most of the analysed maps (82.1\%), the information load is optimal. Maps with high information load were not found. Maps with low information load account for about $18 \%$.

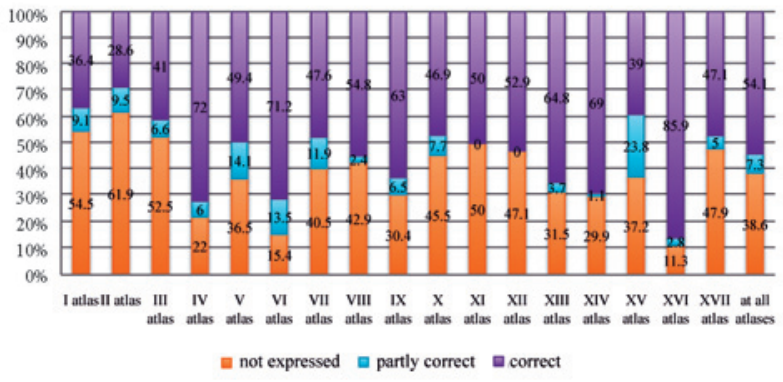

Fig. 4. Semantic differentiation in the legends of the analysed maps of scholastic geographic atlases (\%)

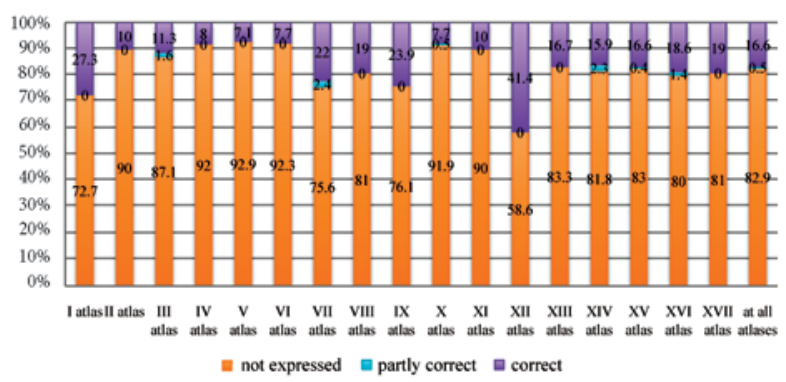

Fig. 5. Taxonomic differentiation (representation of hierarchic relations) in the legends of the analysed maps of scholastic geographic atlases (\%)

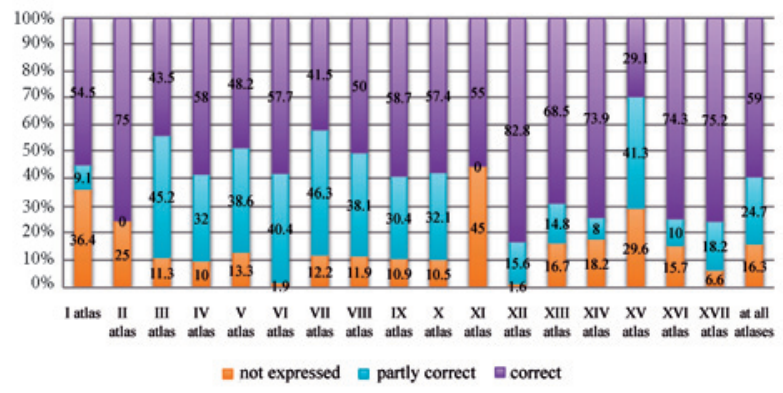

Fig. 6. Transitive expression in the analysed maps of scholastic geographic atlases (\%)

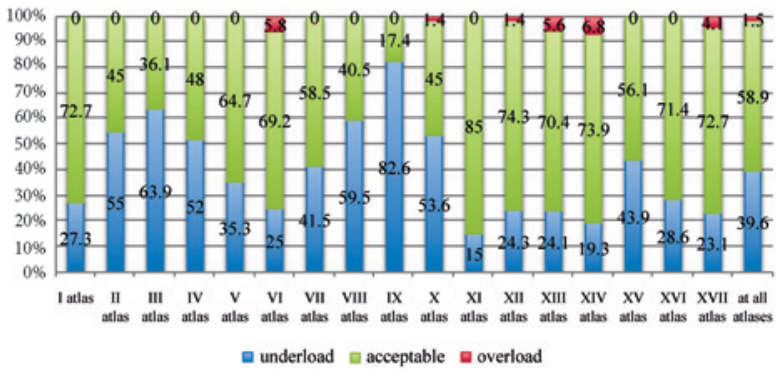

Fig. 7. Graphic load in the analysed maps of scholastic geographic atlases (\%)

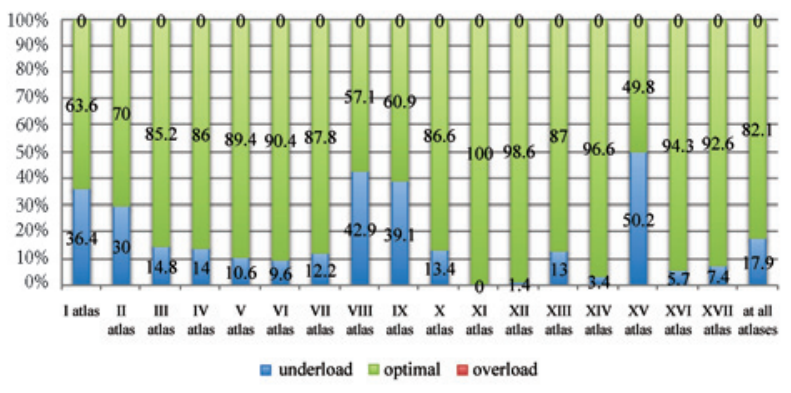

Fig. 8. Information load in the analysed maps of scholastic geographic atlases (\%) 
Cartographic basis, i.e. mathematic basis and geographical elements, is of key importance for perception.

Evaluation of cartographic basis showed (Fig. 9) that even in $46 \%$ of analysed maps cartographic basis was not optimal, in $1 / 3$ of maps it was optimal and in almost $23 \%$ it was medium optimal.

Graphic originality is another very important index in scholastic cartographic production yet

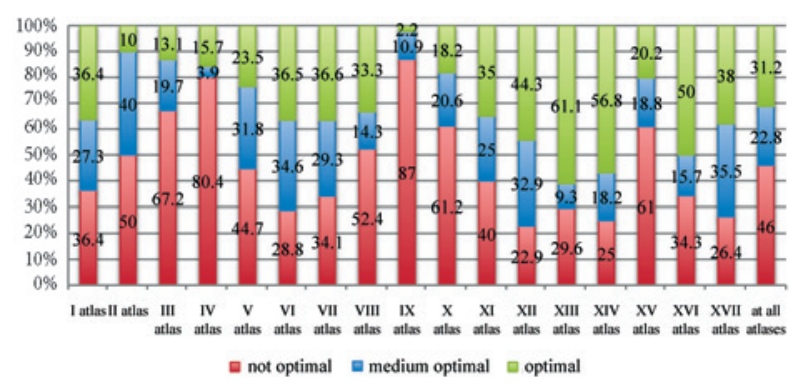

Fig. 9. Optimality of cartographic basis in the analysed maps of scholastic geographic atlases (\%)

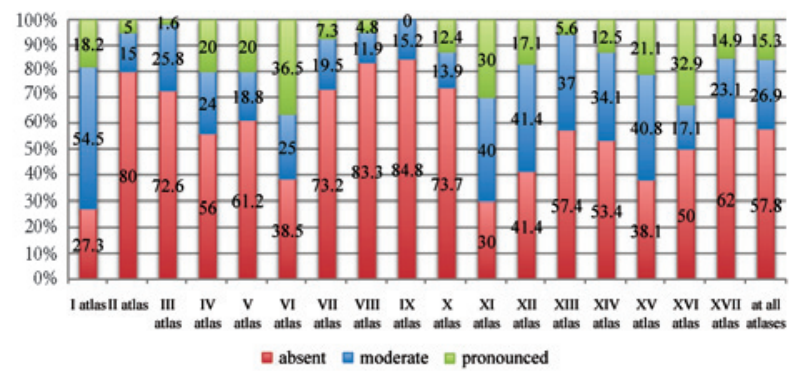

Fig. 10. Graphic originality in the analysed maps of scholastic geographic atlases (\%)

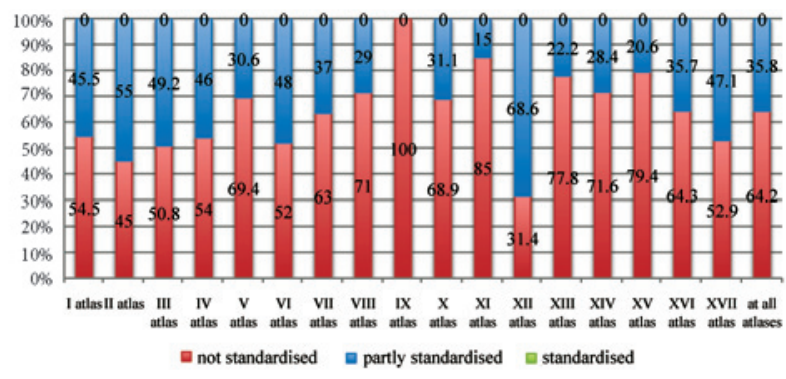

Fig. 11. Standardisation in the analysed maps of scholastic geographic atlases (\%)

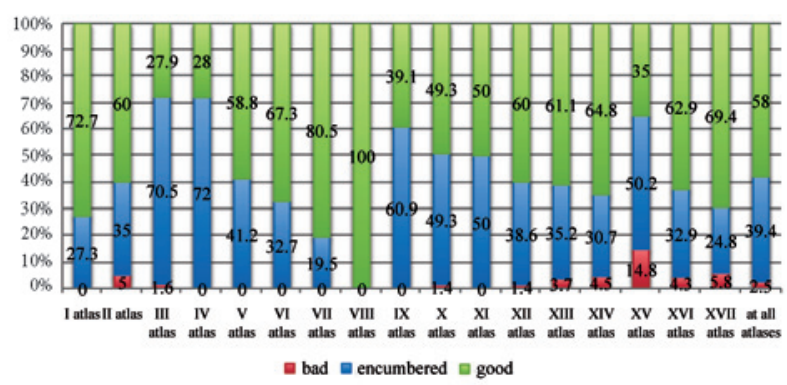

Fig. 12. Readability in the analysed maps of scholastic geographic atlases (\%) neglected by map compilers (Fig. 10). More than a half of the analysed maps (57.8\%) showed no graphic originality. Moderate graphic originality was characteristic of more than $1 / 4$ of analysed maps. Original graphic representation techniques (pronounced graphic originality) was observed in $15.3 \%$ of analysed scholastic geographical maps.

Analysis of the systems of cartographic signs revealed that systems of signs used in some thematic maps were at least partly developed sticking to certain standards, e.g. soil, geological, and physical (relief) maps. These maps together with synoptic, nature zones and geomorphological maps (where systems of signs are not officially standardised but based on certain traditions) can be attributed to the group of partly standardised maps.

The systems of cartographic signs in the majority of the maps of scholastic geographical atlases are not standardised. Such maps account for $64.2 \%$ of the total. Partly standardised systems of signs are used in more than $1 / 3$ of all maps (Fig. 11).

The above discussed indices of pragmatic aspects play the key role in the process of communication, i.e. they are responsible for readability of cartographic production. Readability should be the main objective pursued by map compilers. Yet the task is difficult.

The readability of more than a half (58\%) of analysed maps (Fig. 12) is good. Maps of encumbered readability account for slightly less than $40 \%$ of maps. The readability of $2.5 \%$ of analysed maps is bad.

\section{Conclusions}

Semiotic evaluation of the systems of cartographic signs used in the Lithuanian scholastic geographical maps leads to the conclusions given below.

The present semiotic analysis confirmed the results of semiotic evaluation of economic maps designed for higher forms carried out in 2009. The majority of published maps are schematic, representing one or a few simple objects, phenomena or processes. For this reason, the hierarchic relations between cartographic signs are rarely represented in the legends. The transitive expression is rarely depicted, the maps are not overloaded with information, and cartographic production with optimal information load is dominant. It should be pointed out that often the information load does not increase even in the maps designed for higher forms. The cartographic basis in almost a half of the analysed maps is not optimal what encumbers the readability of cartographic image. 
The relatively small Lithuanian market abounds in scholastic geographical atlases using a huge number of not standardised cartographic signs. Sometimes even the atlases issued by one publishing house use different cartografphic signs for representation of the same objects, phenomena or processes bringing confusion into the process of perception and assimilation of cartographic information. It is necessary to standardise on a national level the systems of cartographic signs for groups of maps included in scholastic geographical atlases.

Pupils are an especially specific group of users of cartographic production. To attract their attention it is necessary to convey the cartographic information using interesting cartographic methods, original shapes of cartographic signs, well matched harmonious colours, and original styles and shades. These things are lacking in the available scholastic cartographic production. Compilers of cartographic production should devote more time not only to collection of information but also to its interesting and original representation.

Map compilers put great efforts to assimilation and use of modern technologies but forget to take count of the specific features of perception by pupils. They also sometimes ignore rules of semiotics without which creation of production of high communicative quality is impossible.

\section{References}

Berliant, A. M. 2003. Kartovedenie. Moskva: Aspekt Press.

Berliant. A. M. 1986. Obraz prostranstva: karta i informatsiia. Moskva: Mysl.

Bertin, J. 1981. Graphics and graphic information-processing. New York: Walter de Gruyter \& Co. http://dx.doi.org/10.1515/9783110854688

Bevainis, L. 2009. The problems of optimization of graphic information loads of training for geography teachers, in Proceedings of IGU Commission on Geographical Education, Tsukuba, Vol. 57: 177-182.

Bevainis, L. 2011a. Analoginiu ir skaitmeniniu edukaciniu žemèlapiu kartografinio vaizdo analize ir vertinimas (grafinès ir informacines apkrovos pagrindu) [The analysis and evaluation of cartographical images of educational digital and paper maps (On the basis of graphic information load)]. Daktaro disertacija [Doctoral dissertation]. Vilnius: VU.

Bevainis, L. 2011b. The problems to determine correct graphic information loads of training maps for geography teaching, Pedagogika 101: 69-77.

Dumbliauskienè, M. 2000. Teminiu žemélapiu kvalimetriné analizè (Lietuvos Respublikos leidiniu komunikacines kokybès pavyzdžiu) [Qualimetric analysis of thematic maps (case study of communicative quality of publications in the Republic of Lithuania)]. Daktaro disertacija [Doctoral dissertation]. Vilnius: VU.

Dumbliauskienè, M. 2004. Kartografinių ženklų teminiuose žemélapiuose standartizacijos problema [Problem of standardisation of cartographic signs in thematic maps], Geografija [Geography] 40(1): 48-53.

Dumbliauskiene, M. 2002. Kartografinès komunikacijos pagrindai [Fundamentals of cartographic communication]. Vilnius: VU.

Dumbliauskienè, M.; Ročiūtè, I. 2009. Ženklų sistemos mokyklinių geografijos atlasų ùkio žemèlapiuose semiotiniu aspektu [Semiotic aspect of the systems of signs in the economic maps of scholastic geographical atlases], Geodesy and Cartography 35(4): 144-151.

Gurčinienė, O. 2007. Jutimo ir suvokimo mechanizmai [Mechanisms of senses and perception]. Vilnius: VU leidykla.

Gurčinienè, O.; Šoliūnas, A. 2005. Ivvairaus simetrijos laipsnio daugiakampių simetrijos aptikimo ypatumai [Pecularities of symmetry detection in polygons with different degree of symmetry], Psichologija [Psychology] 31: 101-112. ISSN 1392-0359

Kaffemanas, R. 1997. Suvokimo psichologija [Perception psychology]. Šiauliai: ŠU l-kla.

Kaffemanas, R. 2001. Mąstymo psichologija [Cogitative psychology]. Šiauliai: ŠU l-kla.

Kaffemanas, R. 2002. Jutimo psichologija [Sense psychology]. Šiauliai: ŠU l-kla.

MacEachren, A. M. 2004. How maps work. Representation, visualization and design. New York: Guilford Press.

Martišius, V. 2008. Kognityvine psichologija. I dalis. Suvokimas ir atmintis [Cognitive psychology. Part I: perception and memory]. Kaunas: Vytauto Didžiojo universiteto leidykla.

Ročiūtè, I. 2009. Kartografinių ženklu sistemu Lietuvos mokykliniuose geografijos atlasuose suvokimo tyrimas [Analysis of perception of cartographic sign systems in Lithuanian geography atlases for school]. Magistro baigiamasis darbas [Master's thesis]. VU, Vilnius.

Ročiūtė, I.; Dumbliauskienė, M. 2009. Kartografinių ženklų suvokimo tyrimas Lietuvos mokyklose [Analysis of the perception of cartographic signs in Lithuanian schools], Geografija [Geography] 45(1): 18-24.

Rociute, I.; Dumbliauskiene, M. 2011. Analysis of perception of cartographic sign systems in Lithuanian geography atlases for school, in Proceedings of the 25th International Cartographic Conference, 3-8 July, 2011, Paris, France [online], [cited 19 March 2013]. ISBN 978-1-907075-05-6, ID CO287. Available from Internet: http://icaci.org/documents/ ICC_proceedings/ICC2011/

Stanikūnas, R.; Vaitkevičius, H.; Švegžda, A.; Viliūnas, V.; Daugirdienè, A.; Kulikowski, J. J.; Murray, I. J. 2004. Du objektų spalvų suvokimo procesai [Two processes in object colour perception], Psichologija [Psychology] 30: 7-16.

Vaitkevičius, P. H. 2002. Pojūčiai ir suvokimas. Regimujų vaizdu suvokimas [Senses and perception. Perception of visual images]. Vilnius: VU leidykla.

Wiegand, P. 2006. Learning and teaching with maps. UK: Routledge. http://dx.doi.org/10.4324/9780203477793

Inga ŽALALIENĖ. PhD student at the Department of Geography and Land Management, Faculty of Natural Sciences, Vilnius University, M. K. Čiurlionio g. 21, 03101 Vilnius, Lithuania. Ph +370 603 17522, e-mail: inga_rociute@gf.stud.vu.lt. MSc from Vilnius University, 2003.

Research interests: cartographical semiotic. 